\title{
Original article \\ A Optimisation of convective drying of carrots using selected 1 processing and quality indicators
}

\author{
Juliana Gamboa-Santos, ${ }^{1}$ Ana C. Soria, ${ }^{2}$ Tiziana Fornari, ${ }^{1}$ Mar Villamiel ${ }^{1} *$ \& Antonia Montilla ${ }^{1}$ \\ 1 Instituto de Investigación en Ciencias de la Alimentación (CIAL) (CSIC-UAM), CEI (CSIC + UAM), Nicolás Cabrera, 9. 28049, \\ Madrid, Spain \\ 2 Instituto de Química Orgánica General (CSIC), Juan de la Cierva, 3. 28006, Madrid, Spain
}

(Received 13 July 2012; Accepted in revised form 27 November 2012)

\begin{abstract}
Summary The effect of drying temperature $\left(40-65^{\circ} \mathrm{C}\right)$ and air rate $\left(2-6 \mathrm{~m} \mathrm{~s}^{-1}\right)$ on the formation of Maillard reaction indicators and vitamins content of carrots dehydrated by convection has been investigated. The range of assayed processing conditions, based on a previous central composite face design (CCD), led to moderate changes in the studied parameters, even under the most severe conditions. In addition, the drying kinetic of the process was studied taking into account the experimental quantitation of shrinkage, which allowed the determination of a first drying period with a constant rate of wate ${ }^{\text {poration }}$ per unit of exchange surface. The slope of the first drying period, the moisture loss duringe $\overline{\bar{n}}$ st hour of drying and the level of quality parameters (Maillard reaction indicators and vitamins) were correlated with processing conditions with high accuracy. For the prototype here used, the optima temperature and air rate to maximise the desirability function $(0.77)$ were $46^{\circ} \mathrm{C}$ and $4.9 \mathrm{~m} \mathrm{~s}^{-1}$.
\end{abstract}

Keywords 2-furoylmethyl-aminoacids, carrot, convective drying, drying kinetic, Maillard reaction, response surface methodology, shrinkage, vitamins.

\section{Introduction}

Nowadays, the trends in food technology are addressed to the intake of nutritive and appealing foods, which provide some health benefits to the consumers. Due to the present "style of life", dried foods and particularly vegetables, have a predominant position in the market of many countries and this is expected to increase even more over the next decade (Zhang et al., 2006). Longer shelf-life, product diversity and volume reduction are the main reasons for the popularity of dried vegetables (Lewicki, 2006).

Carrot (Daucus carota L.) constitutes an important vegetable for human nutrition due to its high vitamin, fibre and other valuable nutrients content and to its organoleptic properties. It is used fresh or dehydrated in the elaboration of a number of foodstuffs, such as soups, salads, sauces, prepared meals and snacks. The importance of carrot is reflected by its global production, which was estimated at 27 million metric tonnes in 2004 (Brunke, 2006).

Dried vegetables are mainly obtained using hot air drying (Lewicki, 2006), being temperature, air-flow rate

*Correspondent: Fax: + 34910017905 ;

e-mail: m.villamiel@csic.es and sample thickness the main parameters affecting the characteristics of the final product (Doymaz, 2004). This process may cause irreversible chemical, physical and sensorial changes. At the low water activity and temperature conditions reached during drying, the Maillard reaction (MR), which involves reducing carbohydrates and free amino groups of amino acids, peptides and proteins, can take place (Cardelle-Cobas et al., 2005). Thus, 2-furoylmethyl-amino acids (2-FMAA), formed at the early stages of MR, have been suggested as sensitive indicators in several dehydrated vegetables (Sanz et al., 2001; Cardelle-Cobas et al., 2005). These indicators have also been found in carrot submitted to different drying processes, such as sola drying (Rufián-Henares et al., 2008), industrial and laboratory convective drying (Soria et al., 2009; Wellner et al., 2011) and ultrasound-assisted convective drying (Soria et al., 2010). In this concern, particularly interesting is the case of the formation of 2-furoylmethyl-lysine (furosine), as its early detection can prevent advanced stages of the MR in which important losses of nutritive value due to the participation of lysine are produced (Corzo-Martínez et al., 2012). Other irreversible changes in the dried product can be related to vitamin losses and modification in texture, rehydration capability, flavour, colour and appearance (Lewicki, 2006). 
During the last years, due to the increased consumer's awareness for better quality, safety and nutritional value of foods, drying research has been addressed towards the improvement of existent and/or emergent processing technologies, which give rise to final products with improved characteristics. One of the most common approaches to guarantee optimal quality of the final product is through careful process design. Thus, by means of tools, such as modelisation and optimisation of the process, the efficiency of the drying can be improved. A number of studies related to the modelisation of drying kinetics of carrot using convective dryers (Mulet, 1994; Singh \& Gupta, 2007; Zielinska \& Markowski, 2010), semi-industrial continuous convective dryers (Aghbashlo et al., 2009), or convective dryers assisted by ultrasound (García-Pérez et al., 2007; Carcel et al., 2011) have been conducted. In those studies, the selection of optimal conditions to obtain premium quality products is carried out by taking into account the interaction of selected processing parameters. In this sense, response surface methodology (RSM) is widely recognised as an important tool for process and product improvement. RSM enables to determine the relationship between the experimental factors (experimental drying variables) that simultaneously optimise the analysis variables (quality parameters) and maximise the desirability function (Myers et al., 2004). In several recent publications, RSM has been used for different drying procedures of artichoke and soybean (Icier, 2010), potato (Eren \& KaymakErtekin, 2007) and berries (Mitra \& Meda, 2009). In carrots, RSM has been used for the optimisation of osmotic dehydration (Kargozari et al., 2010; Singh et al., 2010; Sutar \& Prasad, 2011) and fluidised bed processes (Mudahar et al., 1989; Nazghelichi et al., 2011). Aghbashlo et al. (2011) analysed the variation in the kinetic of carrot drying with the independent variables time, air temperature, air velocity and cube size. Finally, Frías et al. (2010) used RSM to study the effect of convective air drying of carrot on vitamin $\mathrm{C}$ and $\beta$-carotene retention; however, in that study the drying kinetics was not studied. Moreover, to the best of our knowledge, no previous data have been reported in the literature on the optimisation of convective drying of carrots based on 2-FM-AA data, as sensitive quality parameters.

In this study, the effect of processing conditions (drying temperature and air rate) of a prototype by convection on quality indicators (Maillard reaction indicators and vitamins) and drying kinetic of sliced carrot have been reported. To this aim, an experimental design using a central composite face design (CCD) was first carried out and, then, the selected drying and quality parameters were related using a RSM to find the optima processing conditions leading to dehydrated carrots of the best quality.

\section{Materials and methods}

\section{Samples}

Fresh carrots (D. carota L. var. Nantesa) were purchased from a local market in Madrid (Spain). The selection of carrots was based on similar size, optimum colour and ripeness stage. After sorting, they were stored at $4{ }^{\circ} \mathrm{C}$ for, as maximum, 5 days. Before processing, carrots were washed in tap water to remove dust and other residues and were peeled and sliced $(4.0 \pm 0.5 \mathrm{~mm}$ thickness and $24.0 \pm 0.4 \mathrm{~mm}$ diameter $)$. Sliced carrot samples were blanched in boiling water for 1 min (sample:water ratio was 1:12), cooled to room temperature in cold water and then dried with tissue paper to remove superficial water.

\section{Drying equipment}

Blanched carrot samples were dried by convection using a computer controlled (Edibon Scada Control and Data Acquisition Software) air tray dryer (SBANC, Edibon Technical Teaching Units, Spain; Figure S1). This system consists of three main sections: (i) fan unit with air rate control (AVE), (ii) temperature control (seven temperature sensors: ST1, ST4 and ST6 (dry bulb); ST2, ST5 and ST7 (wet bulb) and ST3 sensor of electrical resistance (AR)) and (iii) drying compartment (load cell with four drying trays). Although AR $\left({ }^{\circ} \mathrm{C}\right)$ was the setpoint temperature, ST7 $\left({ }^{\circ} \mathrm{C}\right)$ was chosen as representative of the process temperature, as it was the wet bulb measurement closest to the sample. The air flow was parallel to the sample and the air rate was selected using the AVE $\left(\mathrm{m} \mathrm{s}^{-1}\right)$ sensor. Experimental air-flow rate $\left(\mathrm{m}^{3} \mathrm{~h}^{-1}\right)$ was verified at the output nozzle (area $=0.01 \mathrm{~m}^{2}$ ) using a thermo-anemometer (TESTO, 425, Lenzkirch, Germany). During the drying process, the weight of the samples was automatically monitorised by the load cell of the system (SF, Figure S1). In addition, carrot samples were weighted at $1 \mathrm{~h}$ intervals using an external digital balance for control of accuracy of data (SOEHNLE, Murrhardt, Germany).

\section{Moisture content and drying kinetic curves}

The kinetic curves representing the variation in the moisture content of carrots with convective drying time were calculated as follows:

$$
X(t)=(W(t)-D M) / D M
$$

Where $X$ : moisture content $\left(\mathrm{kg} \mathrm{H}_{2} \mathrm{O} \mathrm{kg}^{-1} \mathrm{DM}\right)$ determined according to Geankoplis (1998); $t$ : drying time (h); $W_{t}$ : sample weight $(\mathrm{kg}) ; \equiv$ : dry matter $(\mathrm{kg})$ determined according to A.O.A.C.(1990a). 
A polynomial approximation $(n=3)$ to the drying curve was proposed to fit the drying process. In agreement with Górnicki \& Kaleta (2007), the first part of the drying curve was described by applying a linear regression model, assuming that a constant drying rate occurred during the first stage of process. Then, the drying rate decreased during the second or fall drying rate period. In the present study, the end of the first constant drying period was considered by means of parameter $t^{*}$, defined as the period of time for which a linear regression of the drying curve can be attained with a $\mathrm{R}^{2} \geq 0.99$. In this point, the sample reached the critical moisture content $\left(X^{*}\right)$. The slope $(S)(\mathrm{kg}$ $\mathrm{H}_{2} \mathrm{O} \mathrm{kg}^{-1} \mathrm{DM} \mathrm{min}{ }^{-1}$ ) of this trend line was also considered in the studied model.

\section{Determination of shrinkage}

To analyse the influence of shrinkage in the drying rate of the process, the thickness (l) and diameter (d) of carrots subjected to drying, were measured in triplicate (slices were selected at random) at 30 min-intervals using a vernier calliper (Mitutoyo Corp., Japan; error $\pm 0.05 \mathrm{~mm})$. Then, the real exchange surface area (A) was calculated as follows:

$$
A=\pi d(d / 2+l)
$$

In the previous equation, it is assumed that the cylindrical shape of carrots is maintained throughout the drying process; this assumption was supported by experimental observation of carrot slices, until the very last part of the falling-rate drying period.

The water flux $\left(q_{t}\right)$ averaged over the exchange surface area of carrot slice was calculated as previously defined by May \& Perre (2002):

$$
q_{t}=-\frac{D M}{A} \frac{d X(t)}{d t}
$$

where $d X(\mathrm{t}) / d \mathrm{t}$ is the drying rate $\left(\mathrm{kg} \mathrm{H}_{2} \mathrm{O} \mathrm{kg}{ }^{-1} \mathrm{DM}\right.$ $\mathrm{min}^{-1}$ ), which was calculated from the experimental drying curves.

\section{Analysis of 2-furoylmethyl-amino acids}

For determination of 2-FM-AA, $0.25 \mathrm{~g}$ of carrots were hydrolysed with $4 \mathrm{~mL}$ of $\mathrm{HCl} 8 \mathrm{M}$ for $23 \mathrm{~h}$ at $110{ }^{\circ} \mathrm{C}$ under inert atmosphere (helium), using a Pyrex screwcap vial with polytetrafluoroethylene-faced septa (Soria et al., 2010). The resulting hydrolysate was filtered (paper filter Whatman no. 40) and $0.5 \mathrm{~mL}$ were purified in a Sep-Pack $\mathrm{C}_{18}$ cartridge (Millipore, MA) pretreated with $5 \mathrm{~mL}$ of methanol and $10 \mathrm{~mL}$ of water. The filtrate was eluted with $3 \mathrm{~mL}$ of $3 \mathrm{~m} \mathrm{HCl}$.

The 2-FM-AA corresponding to lysine (furosine) and arginine were determined using ion-pair Reversed-
phase-High-performance liquid chromatography (RPHPLC) (Resmini \& Pellegrino, 1991) using a $\mathrm{C}_{8}$ column $(250 \mathrm{~mm}$ length $\times 4.6 \mathrm{~mm}$ internal diameter, Alltech, Lexington, KY) at $37^{\circ} \mathrm{C}$. A binary gradient composed of phase $\mathrm{A}\left(4 \mathrm{~mL} \mathrm{~L} \mathrm{~L}^{-1}\right.$ acetic acid) and phase $\mathrm{B}\left(3 \mathrm{~g} \mathrm{~L}^{-1} \mathrm{KCl}\right.$ in phase A solution) was used. The elution program was as follows: $0-12 \mathrm{~min}: 100 \%$ A; 20-22.5 min: $50 \%$ A and $50 \%$ B; $24.5-30 \mathrm{~min}$ :

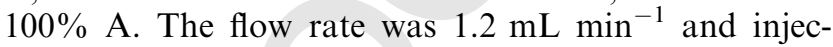
tion $(50 \mu \mathrm{L})$ was carried out using a manual Rheodyne valve. Detection was done at $280 \mathrm{~nm}$ in a LCD Analytical SM 4000 detector.

Quantification was performed using the external standard method, using a commercial standard of furosine (Neosystem Laboratoire, Strasbourg, France). Values were expressed as $\mathrm{mg} \mathrm{kg}^{-1}$ protein and all the analyses were performed in duplicate.

To analyse the protein content of carrot samples under study, total nitrogen (TN) was determined using the Kjeldahl method (A.O.A.C. 1990b). Protein content was calculated using 6.25 as conversion factor $(\mathrm{TN} \times$ $6.25)$.

\section{Optimisation of carrot drying by response surface methodology}

The effect of two independent factors, air rate and temperature, on the convective drying of blanched sliced carrots $(80 \mathrm{~g})$ for up to $6 \mathrm{~h}$ was studied using a central composite face design (CCD, Statgraphic 5.0, Statistical Graphics Corporation, Rockville, MD, USA). A total of ten experiments $\left(2^{2}\right.$ points of a factorial design, four star points and two centre points to estimate the experimental error), were carried out in randomised order. Setpoint parameters, AR and AVE (Figure S1), of assays selected from the experimental design are listed in Table 1.

Four dependent variables were taken into account to optimise the convective drying of carrot by means of RSM: linear time $\left(t^{*}, \mathrm{~min}\right)$, the slope of the linear function of the constant drying rate period $\left(S, \mathrm{~kg} \mathrm{H}_{2} \mathrm{O}\right.$ $\left.\mathrm{kg}^{-1} \mathrm{DM} \mathrm{min}-1\right)$, the weight loss at the first hour of processing $\left(W_{1}, \%\right)$ and the content of 2-FM-Lys + 2-FM-Arg ( $\mathrm{mg} \mathrm{kg}^{-1}$ protein). In addition, the level of vitamin $C$ and $\beta$-carotene, determined in these samples by Frías et al. (2010), were also included in the process optimisation. Each analytical response was evaluated using a one-way analysis of variance (ANOVA), using Fisher's Significant Difference test (LSD, 95\%) (Statgraphics Centurion XV, Statistical Graphics Corporation, Rockville, MD, USA).

The analysis was based on the F-test and on the percentage of explained variance $\left(\mathrm{R}^{2}{ }_{\text {adj }}\right)$, which provides a measurement of how much of the variability in the observed response values could be explained by the experimental factors and their interactions (Myers 
Table 1 Assay conditions (prototype setpoint and experimentally measured) of the experimental design for optimisation of convective drying of carrot

\begin{tabular}{|c|c|c|c|c|}
\hline \multirow[b]{2}{*}{ Assay } & \multicolumn{2}{|c|}{ Prototype setpoint } & \multicolumn{2}{|c|}{ Experimental data } \\
\hline & $\begin{array}{l}\text { Temperature } \\
\left(\mathrm{AR},{ }^{\circ} \mathrm{C}\right)\end{array}$ & $\begin{array}{l}\text { Air rate } \\
\left(A V E, \mathbf{m ~ s}^{-1}\right)\end{array}$ & $\begin{array}{l}\text { Temperature } \\
\text { (ST7, }{ }^{\circ} \mathrm{C} \text { ) }\end{array}$ & $\begin{array}{l}\text { Air flow-rate } \pm \\
\text { SD } \\
\left(\mathrm{m}^{3} \mathrm{~h}^{-1}\right)\end{array}$ \\
\hline A1 & 62 & 2.0 & 52.5 & $67.3 \pm 12.4$ \\
\hline $\mathrm{A} 2$ & 50 & 5.4 & 43.6 & $198.8 \pm 12.5$ \\
\hline A3 & 64 & 4.0 & 52.5 & $154.3 \pm 12.5$ \\
\hline A4 & 53 & 2.6 & 43.6 & $93.0 \pm 8.8$ \\
\hline $\mathrm{A} 5^{\mathrm{a}}$ & $>80$ & 5.4 & 61.4 & $198.8 \pm 12.5$ \\
\hline A6 & 64 & 4.0 & 52.5 & $154.3 \pm 12.5$ \\
\hline A7 & 80 & 4.0 & 65.0 & $154.3 \pm 12.5$ \\
\hline A8 & 72 & 6.0 & 52.5 & $218.8 \pm 11.4$ \\
\hline A9 & 72 & 2.6 & 61.4 & $93.0 \pm 8.8$ \\
\hline A10 & 43 & 4.0 & 40.0 & $154.3 \pm 12.5$ \\
\hline
\end{tabular}

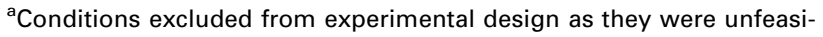
ble to be obtained with the prototype used for convective drying. $A R$, electrical resistance; AVE, air rate control of fan unit; ST7, temperature of wet bulb closest to the sample $\left( \pm 0.5^{\circ} \mathrm{C}\right.$ accuracy).

et al., 2004). The overall effect of the six dependent factors was used to obtain a desirability function that represents the effect of the processing conditions on the final product quality and on the efficiency of drying. It is based on the idea that the "quality" of a process has multiple quality characteristics (Reis et al., 2008). The method finds operating conditions that provide the "most desirable" response values. For processing conditions, a desirability function assigns numbers between 0 (completely undesirable value) and 1 (completely desirable or ideal response). To obtain process optimised, the models that presented an adjusted determination coefficient $\left(\mathrm{R}^{2}\right.$ adj $) \geq 70 \%$ were submitted to simultaneous optimisation, in accordance with the procedures outlined by Granato et al. (2010).

\section{Results and discussion}

\section{Drying kinetic curwes}

Table 1 lists the experimental conditions (ST7 and airflow rate) corresponding to setpoint values (AR and AVE) taken from experimental design. Assay 5 (AR $>80{ }^{\circ} \mathrm{C}$ and $\mathrm{AVE}=5.4 \mathrm{~m} \mathrm{~s}^{-1}$ ) was removed from the experimental design, as the proposed combination of process $\equiv$ onditions was unfeasible to be accomplished usin $\overline{\overline{\bar{\nu}} \mathrm{O}}$ ototype described under "Drying equipment" subsection. ST7 registered temperatures from 40 to $65^{\circ} \mathrm{C}$ that were obtained by setting $\mathrm{AR}$ at temperatures within the range $43-80{ }^{\circ} \mathrm{C}$. A close match was found between AVE values $\left(2-6 \mathrm{~m} \mathrm{~s}^{-1}\right)$ and experimental air rate data (in the range $1.9-6.1 \mathrm{~m} \mathrm{~s}^{-1}$ ) calculated from air-flow rate measured using a thermoanemometer. Blanched carrot samples (with an initial DM of $10.5 \%$ ) processed under the operating conditions listed in Table 1 showed percentages of DM between 84.1 and 89.2. These values are close to those considered as appropriate to preserve the microbiological quality of dehydrated vegetables $(\sim 85 \%$, Belitz \& Grosch, 1997). These values corresponded to an initial moisture content of $9.65 \pm 0.34 \mathrm{~kg} \mathrm{H} \mathrm{H}_{2} \mathrm{O}$ $\mathrm{kg}^{-1} \mathrm{DM}$ for blanched carrot samples and, after drying, the moisture content was in the range $0.44-0.99 \mathrm{~kg} \mathrm{H}_{2} \mathrm{O} \mathrm{kg}^{-1} \mathrm{DM}$.

For each of the assays listed in Table 1 (except for assay A5), variation in the moisture content of the sample as a function of time was calculated from data collected at $1 \mathrm{~h}$ intervals for up to $6 \mathrm{~h}$. Figure 1 depicts the experimental measurements and the corresponding polynomial fit. As expected, the moisture decreased with drying time for all drying processes resulting in different curves depending on the processing conditions of each assay. In general, as it has been described in the literature (Geankoplis, 1998), both the constant rate period and the falling-rate period, described in the drying of solids under constant conditions, were experimentally observed. In the initial period, a vegetable like carrot with high moisture content shows a constant rate of drying. This is due to the fact that evaporation initially takes place near the surface, and water is easily transported to the surface by diffusion. Therefore, the rate of drying would be the same than the rate of free water evaporation. In such conditions, the interface temperature remains constant and the heat is completely used for water evaporation (Geankoplis, 1998).

In the second, falling-rate period, the decrease in drying rate might be related to the reduction in porosity of the material due to shrinkage, with the progress of drying increasing the resistance to movement of water (Lagunez-Rivera et al., 2007; Singh \& Gupta, 2007). In this period, the diffusion of internal moisture to the solid surface is the rate-limiting step, when compared with the rate at which the surface moisture is swept away; therefore, it is the period of diffusioncontrolled drying (Carcel et al., 2007).

Different studies report fruit or vegetable (including carrot) dehydration, with these two periods (Saravacos \& Charm, 1962; Dissa et al., 2008). However, many studies consider that there is no stage of constant rate or it has been assumed that the first period is negligible because of the changes in water content are not linear after a short period from the beginning of drying; therefore, the entire drying process is considered to occur in the range of falling-rate period (Mulet, 1994; García-Pérez et al., 2007; Doymaz, 2008; Arslan $\&$ Mehmet, 2010). These contradictory reported results could be related, among other factors, to the importance of considering the shrinkage and shape changes 

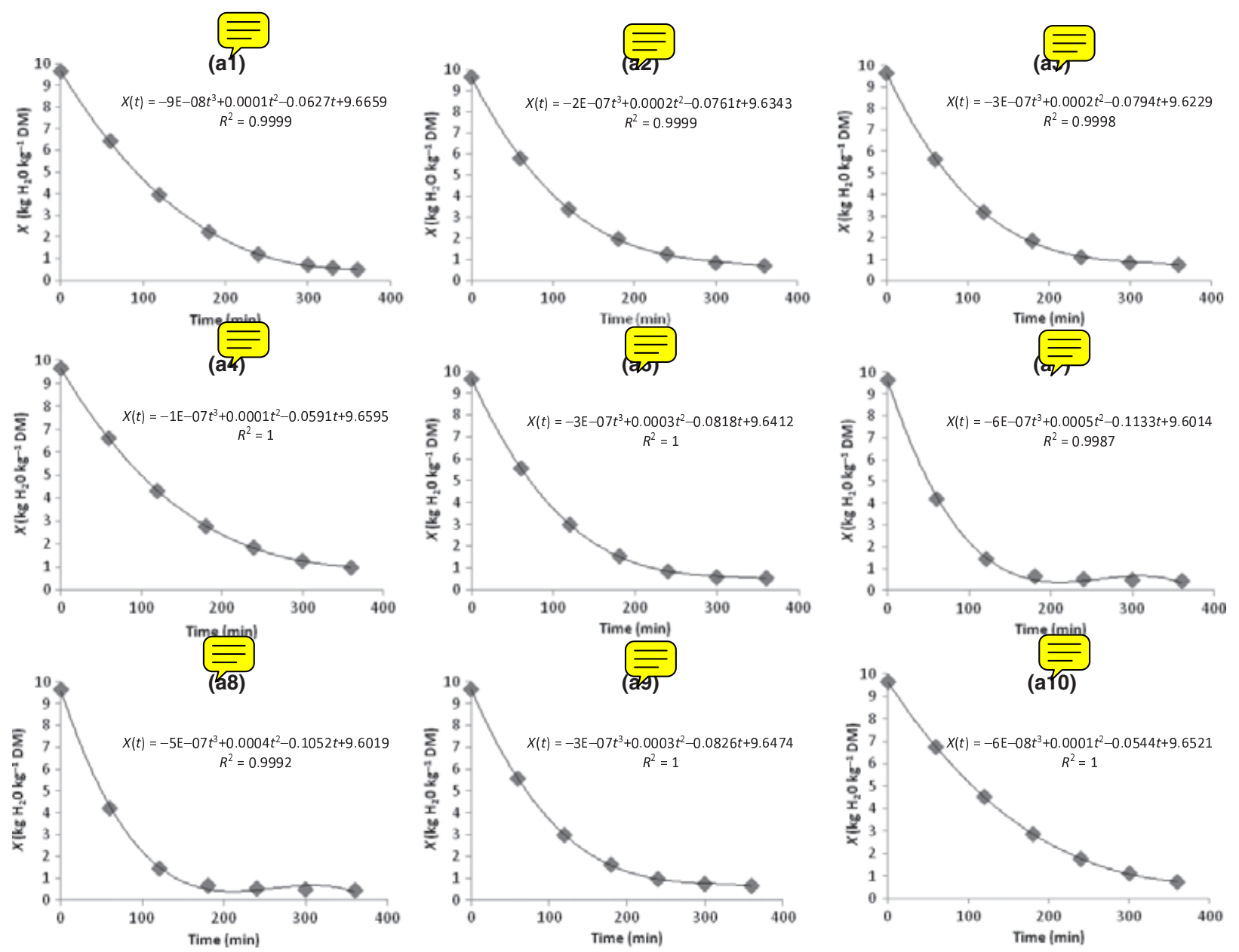

Figure 1 Drying curves at different air-flow rates and temperatures (Table 1) for carrot samples.

during the first period of drying. Thus, during the constant rate period, the shrinkage can be neglected and the conditions of external mass transfer could determine the course of the process (Górnicki \& Kaleta, 2007). However, May \& Perre (2002) and Pabis \& Jaros (2002) stated that in the case of foods with a high initial moisture content, the kinetic model must incorporate the shrinkage factor for better describing the drying results.

To analyse the effect of shrinkage on the drying process, Fig. 2 shows, as an example, the water flux $\left(q_{t}\right)$ as a function of the drying time under the conditions of centre point assays (A3, A6), considering not only the slice surface equal to the initial surface, but also 2 the actual slice surface reported in Table S1. As can be deduced from the figure, a constant rate period was observed when shape changes (reduction in slice surface) were considered. The first section of drying curve of A3 assay is also represented in Fig. 2, together with the $t^{*}$ parameter calculated as the time for which a linear regression of the drying curve can be obtained with a precision of $R^{2}=0.99$. As can be observed, the value of this parameter reasonably corresponds to the constant rate period observed. Then, the $t^{*}$ parameter for each assay of carrot drying was calculated (see Table 2) and was included as a dependent variable in the model analysis. The highest values of $t^{*}$ were found in samples processed under the conditions of assays A1, A4 and A10 (148, 141 and 192 min respectively), which were the mildest of the experimental design; whereas the lowest values of $t^{*}$ were detected in the most intense assays (A7, $81 \mathrm{~min} ; \mathrm{A} 8,85 \mathrm{~min}$ ). Taking into account the $t^{*}$ drying time, the remaining critical moisture content $\left(X^{*}\right)$ was calculated (Table 2$)$, and ranged from 2.4 to $3.9 \mathrm{~kg} \mathrm{H}_{2} \mathrm{O} \mathrm{kg}{ }^{-1} \mathrm{DM}$ depending on processing conditions, values similar to those reported by May \& Perre (2002) for convective drying of carrots $\left(2.8 \mathrm{~kg} \mathrm{H}_{2} \mathrm{O} \mathrm{kg}{ }^{-1} \mathrm{DM}\right)$. According to Dissa et al. (2008), the value of this remaining moisture can be considered as the critical moisture for each drying process, as it separates both constant and falling-rate periods. 


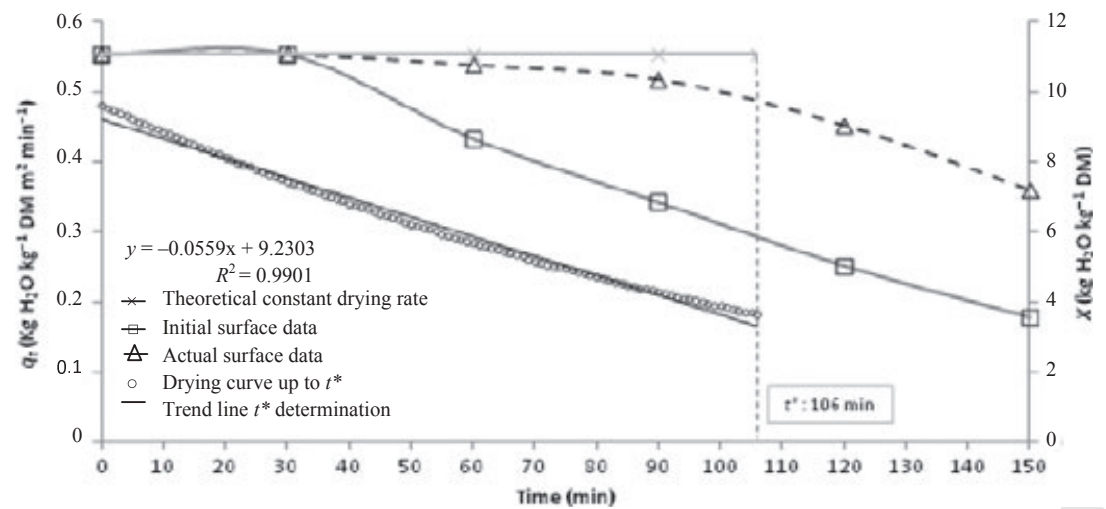

Figure 2 Water flux $\left(q_{t}\right)$ and moisture content $(X)$ vs. time for the first stage of drying curve at the centre point.
Table 2 Values of $t^{*}$ (linear time) $\equiv$ critical moisture content), $S$ (constant rate period of drying), $W$ Wweight loss at the first hour of processing) and concentration of 2-FM-AA (average \pm SD) at the end of the processing of carrot samples.

\begin{tabular}{|c|c|c|c|c|c|}
\hline Assay & $t^{*}(\min )$ & $\begin{array}{l}X^{*} \\
\left(\mathrm{~kg} \mathrm{H}_{2} \mathrm{O}\right. \\
\left.\mathrm{kg}^{-1} \mathrm{DM}\right)\end{array}$ & $\begin{array}{l}S \\
\left(\mathrm{~kg} \mathrm{H}_{2} \mathrm{O} \mathrm{kg}^{-1}\right. \\
\left.\mathrm{DM} \mathrm{min}^{-1}\right)\end{array}$ & $W_{1}(\%)$ & $\begin{array}{l}\text { 2-FM-Lys + } \\
\text { 2-FM-Arg } \\
\text { (mg kg }^{-1} \\
\text { protein) }\end{array}$ \\
\hline A1 & 148 & 3.5 & -0.044 & 30.5 & $393 \pm 23$ \\
\hline A2 & 106 & 3.9 & -0.054 & 36.2 & $\operatorname{tr}$ \\
\hline A3 & 106 & 3.7 & -0.056 & 37.8 & $445 \pm 19$ \\
\hline A4 & 141 & 3.8 & -0.042 & 28.5 & $\operatorname{tr}$ \\
\hline A5 & - & - & - & - & - \\
\hline A6 & 106 & 3.3 & -0.058 & 37.8 & $431 \pm 1$ \\
\hline A7 & 81 & 3.2 & -0.080 & 50.9 & $1689 \pm 152$ \\
\hline A8 & 85 & 3.2 & -0.074 & 48.1 & $1583 \pm 20$ \\
\hline A9 & 105 & 3.5 & -0.058 & 38.3 & $705 \pm 35$ \\
\hline A10 & 192 & 2.4 & -0.038 & 272 & $\operatorname{tr}$ \\
\hline
\end{tabular}

$\mathrm{tr}$, trace value; DM, dry matter $(\mathrm{kg})$. For RSM op fimization, trace values were replaced by an arbitrary numeric value of 0.1

Taking into account the $t^{*}$ definition, the drying rate during the constant rate period can be calculated for each experimental assay as the slope $(S)$ of the linear regression obtained. The $S$ values obtained are given in Table 2 and are in agreement with the $t^{*}$ values, namely the higher $t^{*}$, the lower value for the slope, that is the lower drying rate. The highest slopes of the drying curves were obtained for assays A7 and A8 $\left(0.080\right.$ and $0.074 \mathrm{~kg} \mathrm{H}_{2} \mathrm{O} \mathrm{kg}^{-1} \mathrm{DM} \mathrm{min}{ }^{-1}$ respectively), corresponding to the most severe conditions. Several authors have reported that, in general, drying rates increase with the temperature and air-flow rate for various vegetables, including carrot (Velic et al., 2004; Aghbashlo et al., 2009; Zielinska \& Markowski, 2010). However, when the air rate range is narrow $\left(0.5-1 \mathrm{~m} \mathrm{~s}^{-1}\right)$, hardly any effect on drying rate can be detected (Madamba et al., 1996).

During the constant rate drying period, values between 27 and $51 \%$ of weight loss were reached after
$1 \mathrm{~h}$ of drying (Table 2). The highest $W_{l}$ values were observed in the assays carried out under the most severe conditions (A7 and A8), whereas the lowest values for this parameter (about 28\%) were obtained at mild processing conditions (A4, and A10).

\section{Effect of drying on quality indicators}

As afore-mentioned, the formation of 2-FM-Lys + 2-FM-Arg was selected as quality marker of drying process related to the initial steps of evolution of MR. Table 2 depicts the quantitative data of 2-FM-AA for carrots analysed in the present study after $6 \mathrm{~h}$ of dehydration. No formation of 2-FM-AA was detected either in raw or blanched carrots. The highest 2-FM-AA contents (1689 and $1583 \mathrm{mg} \mathrm{kg}^{-1}$ protein) were found in dehydrated carrots after the assays A7 and A8 respectively. The conditions used in these assays were the most severe and also gave rise to the major humidity losses (residual humidity values of 10.8 and $12.7 \%$ ). The intermediate processing conditions (A1, A3, A6 and A9) provoked the formation of 2-FM-AA within the range $393-705 \mathrm{mg} \mathrm{kg}^{-1}$ protein, and only traces of 2-FM-AA were detected in carrot samples processed after assays A2, A4 and A10.

The 2-FM-Lys (furosine) contents of dehydrated carrots analysed in the present study were lower than those previously reported for dehydrated carrots by other authors. Soria et al. $(2009,2010)$ found values from 3580 to $8480 \mathrm{mg} \mathrm{kg}^{-1}$ protein in industrially dried and commercial carrot samples, whereas upper values were obtained by Wellner et al. (2011) for commercial carrot products $\left(15408-15529 \mathrm{mg} \mathrm{kg}^{-1}\right.$ protein) and for carrot slices dried at 70,80 and $90{ }^{\circ} \mathrm{C}$ in an oven during $5 \mathrm{~h}$ (9040-9890 mg kg-1 protein). Rufián-Henares et al. (2008) analysed carrots industrially dehydrated at low temperature $\left(30^{\circ} \mathrm{C}\right)$ during long time $(180 \mathrm{~h})$ and they found values of $4030 \mathrm{mg}$ furosine $\mathrm{kg}^{-1}$ protein. Only in carrots dehydrated by power ultrasound at temperatures up to $60{ }^{\circ} \mathrm{C}$, Soria et al. (2010) reported values of this quality marker 
Table 3 Regression equations for the model fit of the different variables studied during the drying process of carrot
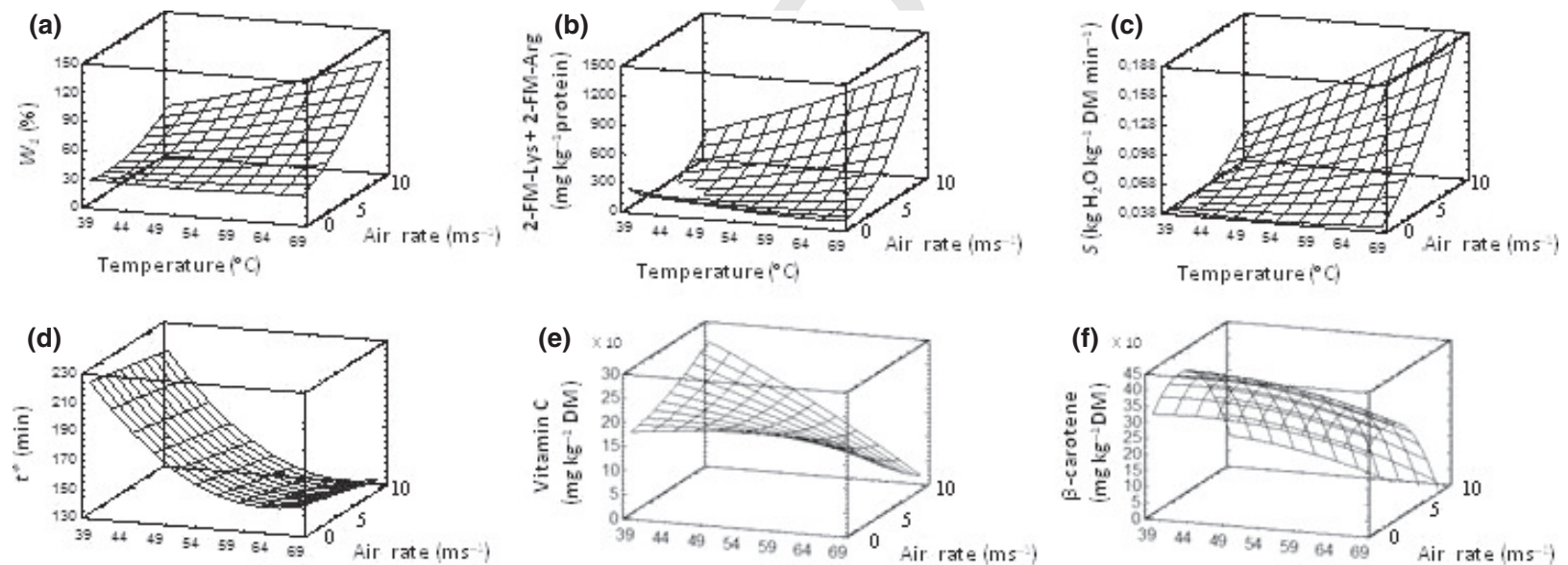

$\equiv$

Temperature $i^{\circ} \mathrm{Cl}$
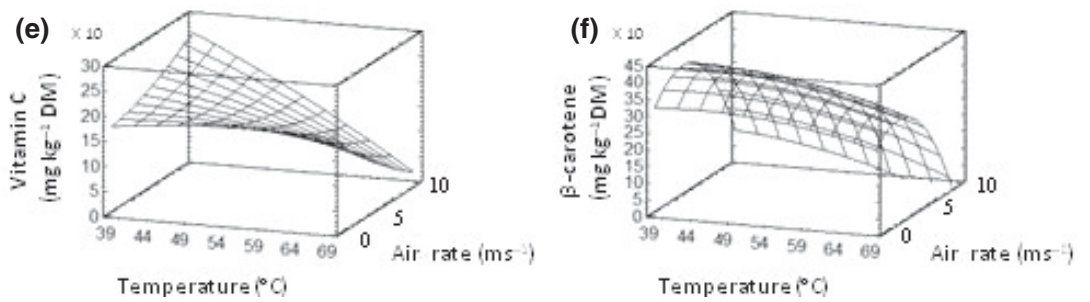

Figure 3 Response surface plots of each analysed variable as a function of temperature and air-flow rate.

significantly lower than those here analysed (390 mg $\mathrm{kg}^{-1}$ protein).

These results highlight the limited progress of MR during the dehydration process of carrot carried out in our convective system, even under the most severe conditions of temperature and air flow, and the importance of optimising the process to obtain premium quality products, as kinetic of this reaction is strongly dependent on temperature and water content throughout the treatment.

\section{Optimisation of processing conditions by response surface methodology}

In order to optimise the drying process, operating conditions (air rate and drying temperature) of assays
1-10 were related by means of RSM with each of the dependent variables under study: parameters derived from drying curves $\left(t^{*}, S\right.$ and $\left.W_{1}\right)$ and quality parameters (2-FM-AA, vitamin $\mathrm{C}$ and $\beta$-carotene). The equations of the fitted models and the corresponding estimated responses surfaces are shown in Table 3 and Fig. 3, respectively. Together with the equations of the fitted models given in Table 3, the $R^{2}$ and $R_{\text {adj }}^{2}$ statistics values are also shown. As it can be observed, with the exception of $t^{*}$-value, all the variables presented high values of $R^{2}$ and $R^{2}$ adj indicating the goodness of the fits (Granato et al., 2010). The slopes of the constant rate period present high regression values $\left(R^{2}=98.9 \%\right.$ and $\left.R_{\text {adj }}^{2}=97.1 \%\right)$, showing that this variable can be maximised in the optimisation by RSM, to attain the shorter times during the drying 
Table 4 Predicted and observed values for the desirability function during the different assays of drying of carrots by convection

\begin{tabular}{|c|c|c|}
\hline \multirow[b]{2}{*}{ Assay } & \multicolumn{2}{|l|}{ Desirability } \\
\hline & Predicted & Observed \\
\hline $\mathrm{A} 1$ & 0.61 & 0.61 \\
\hline $\mathrm{A} 2$ & 0.74 & 0.78 \\
\hline A3 & 0.73 & 0.73 \\
\hline A4 & 0.51 & 0.58 \\
\hline A5 & - & - \\
\hline A6 & $0.73(\bar{\equiv})$ & $0.73 \overline{\bar{\equiv}}$ \\
\hline A7 & $0.000^{2}$ & 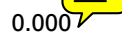 \\
\hline A8 & 0.40 & 0.34 \\
\hline A9 & 0.59 & 0.57 \\
\hline $\mathrm{A} 10$ & 0.56 & 0.41 \\
\hline
\end{tabular}
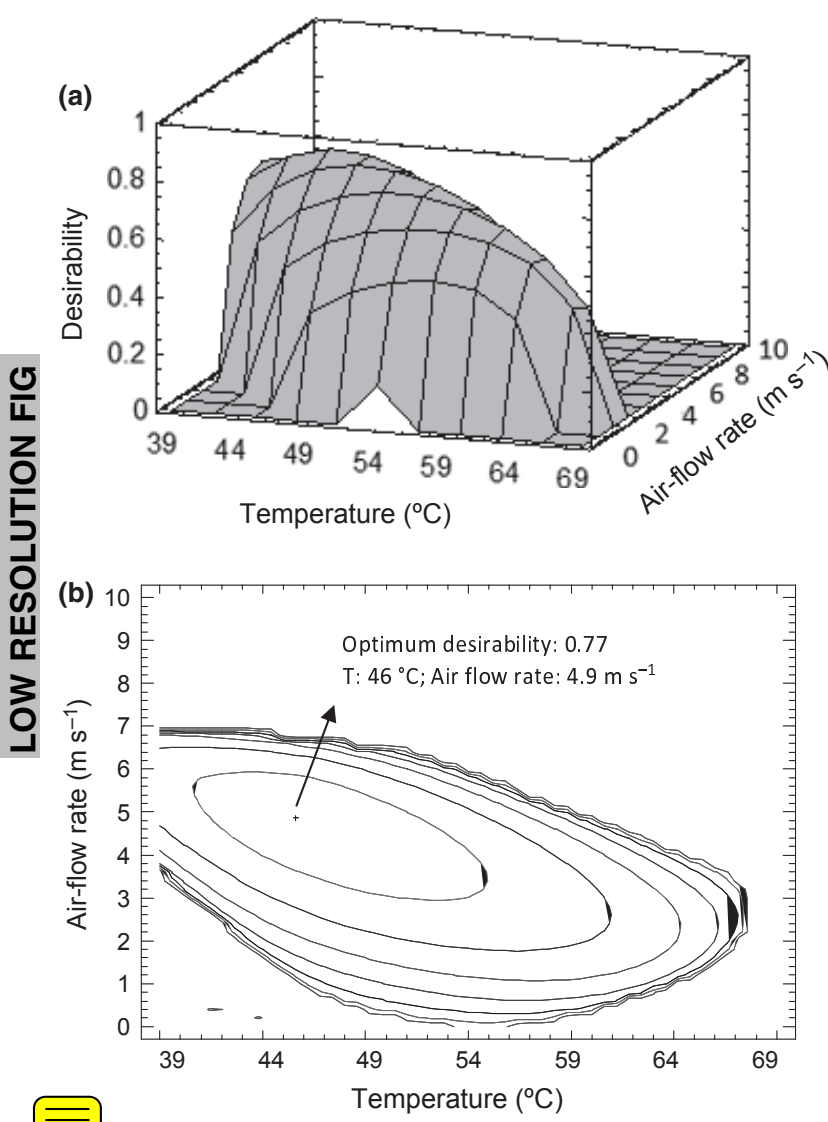

Figure 4 Estimated response surface (a) and the corresponding contour plot (b) for the desirability function.

process. Consequently, the slope and weight loss at the first hour $\left(R^{2}=99.5 \%\right.$ and $\left.R_{\text {adj }}^{2}=98.7 \%\right)$ of each fit were selected as the representative variables of the drying process together with the quality indicators of dried carrot samples, defined as the 2-FM-Lys +
Table 5 Optima values of the different dependent variables to obtain the maximum desirability value corresponding to $46{ }^{\circ} \mathrm{C}$ and $4.9 \mathrm{~m} \mathrm{~s}^{-1}$

\begin{tabular}{|c|c|}
\hline Variables $^{a}$ & Values \\
\hline$S\left(\mathrm{~kg} \mathrm{H}_{2} \mathrm{O} \mathrm{kg}^{-1} \mathrm{DM} \mathrm{min}{ }^{-1}\right)$ & 0.052 \\
\hline$W_{1}(\%)$ & 35.1 \\
\hline 2-FM-Lys+2-FM-Arg (mg kg ${ }^{-1}$ protein) & 153 \\
\hline Vitamin $\mathrm{C}\left(\mathrm{mg} \mathrm{kg}^{-1} \mathrm{DM}\right)$ & 189 \\
\hline B-carotene (mg kg $\left.{ }^{-1} \mathrm{DM}\right)$ & 376 \\
\hline
\end{tabular}

${ }^{\text {a }} S$, constant rate period of drying, $W_{1}$, weight loss at the first hour of processing, 2-FM-AA, 2-furoylmethyl-amino acids.

2-FM-Arg content (measured and reported in this study) and the vitamin $C$ and $\beta$-carotene contents.

In addition, Table 4 compares the value of the desirability function predicted for assays A1-A10, with the values calculated from the corresponding experimental data. This was defined to minimise the 2-FM-AA concentration and maximise the $\beta$-carotene and vitamin $\mathrm{C}$ content, the first hour loss weight $\left(W_{l}\right)$ and the rate of the first drying period $(S)$. The corresponding threedimensional representation of the desirability function obtained is shown in Fig. 4a. This figure illustrates the effect of temperature and air rate on the desirability function. As observed, there is a maximum of predicted desirability (0.77) corresponding to a temperature value of $46^{\circ} \mathrm{C}$ and an air rate of $4.9 \mathrm{~m} \mathrm{~s}^{-1}$. The exact point can be better seen in Fig. $4 b$, which represents the corresponding contour plot. Among the tested conditions, the highest observed value of desirability function was 0.78 , corresponding to A2 assay and 0.73 to the centred points (A3 and A6). Granato et al. (2010) obtained a value of desirability of 0.72 when studying the optimisation of the sensory properties of dairy-free emulsions. Other authors, such as Kargozari et al. (2010), optimising physical properties of osmotically dehydrated carrot cubes, obtained a desirability value of 0.92 . In summary, Table 5 shows the optimal values for the dependent variables obtained by RSM optimisation of the process at $46{ }^{\circ} \mathrm{C}$ and $4.9 \mathrm{~m} \mathrm{~s}^{-1}$.

\section{Conclusion}

An experimental design is here proposed to optimise the operating conditions (temperature and air rate) with regard to selected processing $\left(t^{*}, S\right.$ and $\left.W_{l}\right)$ and quality indicators (advance of MR and loss of vitamins). Furthermore, and to better determine the first drying period with constant rate, which can be described by a linear regression $\left(R^{2}=0.99\right)$ of the drying curve, experimental quantification of shrinkage has also been carried out. In general, mild changes in the advance of $\mathrm{MR}$ and the loss of vitamin $\mathrm{C}$ and $\beta$-carotene were 
observed, even under the most severe conditions assayed, together with moisture loss values within the limits established to guarantee the microbiological stability of the product. RSM analysis of the operating conditions and studied indicators allowed, with high accuracy, the determination of optimal drying parameters $\left(46^{\circ} \mathrm{C}\right.$ and $\left.4.9 \mathrm{~ms}^{-1}\right)$. This study underlines the usefulness of optimising the convective drying of carrots to obtain a long shelf-life product with premium quality (the lowest loss of nutritive value) in the shortest time and with the lowest energy requirement.

\section{Acknowledgements}

This study has been funded by MICINN (project AGL2007-63462 and Fun-C-Food CSD2007-00063 Consolider-INGENIO) and Comunidad de Madrid (project ALIBIRD 2009/AGR-1469). J.G.S. also thanks CSIC and the EU for a predoctoral JAE grant. A.C.S. thanks the Spanish Ministry of Economy and Competitiveness for a Ramón y Cajal contract.

\section{References}

Aghbashlo, M., Hossien, K. \& Akbar, A. (2009). Performance analysis of drying of carrot slices in a semi-industrial continuous band dryer. Journal of Food Engineering, 91, 99-108.

Aghbashlo, M., Kianmehr, M.H., Nazghelichi, T. \& Rafiee, S. (2011). Optimization of an artificial neural network topology for predicting drying kinetics of carrot cubes using combined response surface and genetic algorithm. Drying Technology, 29, $770-779$.

A.O.A.C. (1990a). Official Methods of Analysis of the Association of Official Analytical Chemists (15th edn), Vol. 1.(edited by K. Helrich \& Association of Official Analytical Chemists), Method 950.01. Pp.

3 684. Arlington, VA: A.O.A.C.

A.O.A.C. (1990b). Official Methods of Analysis of the Association of Official Analytical Chemists (15th edn), Vol. 1. (edited by K. Helrich \& Association of Official Analytical Chemists), Method 4 920.165. Pp. 1000. Arlington, VA: A.O.A.C.

Arslan, D. \& Mehmet, M.Ö. (2010). Study the effect of sun, oven and microwave drying on quality of onion slices. LWT - Food Science and Technology, 43, 1121-1127.

Belitz, H. D. \& Grosch, W. (1997). Química de los alimentos (2nd edn.). Zaragoza, Spain: Acribia.

Brunke, H. (2006). Commodity Profile: Carrots. In Agricultural Marketing Resource Centre: Agricultural Issues Centre, University of California, Davis, EEUU.

Carcel, J.A., Garcia-Perez, J.V., Riera, E. \& Mulet, A. (2007). Influence of high-intensity ultrasound on drying kinetics of persimmon. Drying Technology, 25, 185-193.

Carcel, J.A., Garcia-Perez, J.V., Riera, E. \& Mulet, A. (2011). Improvement of convective drying of carrot by applying power ultrasound. Influence of mass load density. Drying Technology, 29, 174-182.

Cardelle-Cobas, A., Moreno, F.J., Corzo, N., Olano, A. \& Villamiel, M. (2005). Assessment of initial stages of Maillard Reaction in dehydrated onion and garlic samples. Journal of Agricultural and Food Chemistry, 53, 9078-9082.

Corzo-Martínez, M., Corzo, N., Villamiel, M. \& del Castillo, M.D. (2012) Browning reactions. In: Food Biochemistry and Food Processing, (edited by Y.H. Hui) Associate editors: W.K. Nip, L.M.L. Mollet, G. Pañiyath \& B.K. Simpson. Iowa, USA: Blackwell Publishing.
Dissa, A.O., Desmorieux, H., Bathiebo, J. \& Koulidiati, J. (2008). Convective drying characteristics of Amelie mango (Mangifera Indica L. cv. 'Amelie') with correction for shrinkage. Journal of Food Engineering, 88, 429-437.

Doymaz, I. (2004). Convective air drying characteristics of thin layer carrots. Journal of Food Engineering, 61, 359-364.

Doymaz, I. (2008). Convective drying kinetics of strawberry. Chemical Engineering and Processing, 47, 914-919.

Eren, I. \& Kaymak-Ertekin, F. (2007). Optimization of osmotic dehydration of potato using response surface methodology. Journal of Food Engineering, 79, 344-352.

Frías, J., Peñas, E., Ullate, M. \& Vidal-Valverde, C. (2010). Influence of drying by convective air dryer or power ultrasound on the vitamin $\mathrm{C}$ and $\beta$-carotene content of carrots. Journal of Agricultural and Food Chemistry, 58, 10539-10544.

García-Pérez, J.V., Carcel, J.A., Benedito, J. \& Mulet, A. (2007). Power ultrasound mass transfer enhancement in food drying. Food and Bioproducts Processing, 85, 247-254.

Geankoplis, C.J. (1998). Secado de materiales de proceso. In: Procesos de transporte y operaciones unitarias (3rd edn) (edited by ??? ??????????). Pp. ????-????. México: Compañía Editorial Continental. 5

Górnicki, K. \& Kaleta, A. (2007). Drying curve modelling of blanched carrot cubes under natural convection condition. Journal of Food Engineering, 82, 160-170.

Granato, D., Bigaski Ribeiro, J.C., Alves Castro, I. \& Masson, M.L. (2010). Sensory evaluation and physicochemical optimisation of soy-based desserts using response surface methodology. Food Chemistry, 121, 899-906.

Icier, F. (2010). Ohmic blanching effects on drying of vegetable byproduct. Journal of Food Process Engineering, 33, 661-683.

Kargozari, M., Moini, S. \& Emam-Djomeh, Z. (2010). Prediction of some physical properties of osmodehydrated carrot cubes using response surface methodology. Journal of Food Processing and Preservation, 34, 1041-1063.

Lagunez-Rivera, L., Ruiz-Lopez, I.I., García-Alvarado, M.A. \& Salgado-Cervantes, M.A. (2007). Mathematical simulation of the effective diffusivity of water during drying of papaya. Drying Technology, 25, 1633-1638.

Lewicki, P.P. (2006). Design of hot air drying for better foods. Trends in Food Science \& Technology, 17, 153-163.

Madamba, P.S., Driscoll, R.H. \& Buckle, K.A. (1996). The thinlayer drying characteristics of garlic slices. Journal of Food Engineering, 29, 75-97.

May, B.K. \& Perre, P. (2002). The importance of considering exchange surface area reduction to exhibit a constant drying flux period in foodstuffs. Journal of Food Engineering, 54, 271-282.

Mitra, P. \& Meda, V. (2009). Optimization of microwave-vacuum drying parameters of saskatoon berries using response surface methodology. Drying Technology, 27, 1089-1096.

Mudahar, G., Toledo, R., Floros, J. \& Jen, J. (1989). Optimization of carrot dehydration process using Response-Surface Methodology. Journal of Food Science, 54, 714-719.

Mulet, A. (1994). Drying modelling and water diffusivity in carrots and potatoes. Journal of Food Engineering, 22, 329-348.

Myers, R.H., Montgomery, D.C., Vining, G., Borror, C.M. \& Kowalski, S.M. (2004). Response surface methodology: a retrospective and literature survey. Journal of Quality Technology, 36, $53-55$.

Nazghelichi, T., Aghbashlo, M. \& Kianmehr, M.H. (2011). Optimization of an artificial neural network topology using coupled response surface methodology and genetic algorithm for fluidized bed drying. Computers and Electronics in Agriculture, 75, 84-91.

Pabis, S. \& Jaros, M. (2002). The First Period of Convection Drying of Vegetables and the Effect of Shape-dependent Shrinkage. Biosystems Engineering, 81, 201-211.

Reis, F.R., Masson, M.L. \& Waszczynskyj, N. (2008). Influence of a blanching pretreatment on color, oil uptake and water activity of 
potato sticks, and its optimization. Journal of Food Processing Engineering, 31, 833-852.

Resmini, P. \& Pellegrino, L. (1991). Analysis of food heat damage by direct HPLC of furosine. International Chromatography Laboratory, 6, 7-11.

Rufián-Henares, J.A., García-Villanova, B. \& Guerra-Hernández, E. (2008). Occurrence of furosine and hydroxymethylfurfural as markers of thermal damage in dehydrated vegetables. European Food Research \& Technology, 228, 249-256.

Sanz, M.L., del Castillo, M.D., Corzo, N. \& Olano, A. (2001). Formation of Amadori Compounds in Dehydrated Fruits. Journal of Agricultural and Food Chemistry, 49, 5228-5231.

Saravacos, G.D. \& Charm, S.D. (1962). A study of mechanism of fruit and vegetable dehydration. Food Technology, 16, 78-81.

Singh, B. \& Gupta, A.K. (2007). Mass transfer kinetics and determination of effective diffusivity during convective dehydration of pre-osmosed carrot cubes. Journal of Food Engineering, 79, 459470.

Singh, B., Panesar, P.S., Nanda, V. \& Kennedy, J.F. (2010). Optimization of osmotic dehydration process of carrot cubes in mixtures of sucrose and sodium chloride solutions. Food Chemistry, 123, $590-600$.

Soria, A.C., Olano, A., Frías, J., Peñas, E. \& Villamiel, M. (2009). 2-Furoylmethyl amino acids, hydroxymethylfurfural, carbohydrates and $\beta$-carotene as quality markers of dehydrated carrots. Journal of the Science of Food and Agriculture, 89, 267-273.

Soria, A.C., Corzo-Martinez, M., Montilla, A., Riera, E., GamboaSantos, J. \& Villamiel, M. (2010). Chemical and physicochemical quality parameters in carrots dehydrated by power ultrasound. Journal of Agricultural and Food Chemistry, 58, 7715-7722.
Sutar, P.P. \& Prasad, S. (2011). Modelling mass transfer kinetics and mass diffusivity during osmotic dehydration of blanched carrots. International Journal of Food Engineering, 7, 4-21.

Velic, D., Planinic, M., Tomas, S. \& Bilic, M. (2004). Influence of airflow velocity on kinetics of convection apple drying. Journal of Food Engineering, 64, 97-102.

Wellner, A., Huettl, C. \& Henle, T. (2011). Formation of Maillard Reaction products during heat treatment of carrots. Journal of Agricultural and Food Chemistry, 59, 7992-7998.

Zhang, M., Tang, J., Mujumdar, A.S. \& Wang, S. (2006). Trends in microwave related drying of fruits and vegetables. Trends in Food Science \& Technology, 17, 524-534.

Zielinska, M. \& Markowski, M. (2010). Air drying characteristics and moisture diffusivity of carrots. Chemical Engineering and Processing, 49, 212-218.

\section{Supporting Information}

Additional Supporting Information may be found in the online version of this article:

Figure S1. Drying cabinet (EDIBON) used for the convective drying of carrots.

Table S1. Experimental thickness $(l)$ and diameter (d) (average data \pm standard deviation) and calculated exchange area $(A)$ used to study the influence of shrinkage during drying of carrots under A3 conditions. 


\section{Author Query Form}

\section{Journal: $\quad$ IJFS}

Article: $\quad 12076$

Dear Author,

During the copy-editing of your paper, the following queries arose. Please respond to these by marking up your proofs with the necessary changes/additions. Please write your answers on the query sheet if there is insufficient space on the page proofs. Please write clearly and follow the conventions shown on the attached corrections sheet. If returning the proof by fax do not write too close to the paper's edge. Please remember that illegible mark-ups may delay publication.

Many thanks for your assistance.

\begin{tabular}{|c|c|c|}
\hline Query reference & Query & Remarks \\
\hline A & $\begin{array}{l}\text { Please note that this proof exceeds the journal's free pages allocation } \\
\text { (7pp) and will be subject to an excess page charge. } \\
\text { You have the following options: } \\
\text { - Convert material (for example, figures and tables) from the main arti- } \\
\text { cle text to Supporting Information, which will be linked to the article } \\
\text { and accessible online only. } \\
\text { - Pay excess page charges when the article is published in an issue of } \\
\text { the journal. }\end{array}$ & $\overline{\bar{\equiv}}$ \\
\hline 1 & $\begin{array}{l}\text { AUTHOR: In this title, the word "Optimization" has been changed to } \\
\text { "Optimisation" to conform to UK("S"- spelling) as per journal style } \\
\text { sheet specification and hence followed throughout this article. }\end{array}$ & $\overline{\overline{\bar{v}}}$ \\
\hline 2 & AUTHOR: Table 2S has been changed into Table S1. Please check. & $\overline{\overline{\bar{v}}}$ \\
\hline 3 & $\begin{array}{l}\text { AUTHOR: Please provide Chapter title for the reference A.O.A.C } \\
\text { (1990a). }\end{array}$ & $\bar{\equiv}$ \\
\hline 4 & $\begin{array}{l}\text { AUTHOR: Please provide Chapter title for the reference A.O.A.C } \\
\text { (1990b). }\end{array}$ & $\bar{\equiv}$ \\
\hline 5 & $\begin{array}{l}\text { AUTHOR: Please provide the editor name(s), page range for reference } \\
\text { Geankoplis (1998). }\end{array}$ & $\overline{\overline{\bar{\nu}}}$ \\
\hline 6 & $\begin{array}{l}\text { AUTHOR: Table S2 has been changed into Table S1. Please check } \\
\text { caption. }\end{array}$ & $\overline{\overline{\bar{v}}}$ \\
\hline 7 & $\begin{array}{l}\text { AUTHOR: Figure } 2 \text { has been saved at a low resolution of } 72 \text { dpi. } \\
\text { Please resupply at } 300 \text { dpi. Check required artwork specifications at } \\
\text { http://authorservices.wiley.com/bauthor/illustration.asp }\end{array}$ & $\overline{\bar{\nu}}$ \\
\hline 8 & $\begin{array}{l}\text { AUTHOR: Figure } 3 \text { has been saved at a low resolution of } 72 \text { dpi. } \\
\text { Please resupply at } 300 \text { dpi. Check required artwork specifications at } \\
\text { http://authorservices.wiley.com/bauthor/illustration.asp }\end{array}$ & $\bar{\equiv}$ \\
\hline 9 & $\begin{array}{l}\text { AUTHOR: Figure } 4 \text { has been saved at a low resolution of } 72 \text { dpi. } \\
\text { Please resupply at } 300 \mathrm{dpi} \text {. Check required artwork specifications at } \\
\text { http://authorservices.wiley.com/bauthor/illustration.asp }\end{array}$ & $\overline{\overline{\bar{v}}}$ \\
\hline
\end{tabular}


Required software to e-Annotate PDFs: Adobe Acrobat Professional or Adobe Reader (version 7.0 or above). (Note that this document uses screenshots from Adobe Reader $\mathbf{X}$ )

The latest version of Acrobat Reader can be downloaded for free at: http://get.adobe.com/uk/readerl

Once you have Acrobat Reader open on your computer, click on the Comment tab at the right of the toolbar:

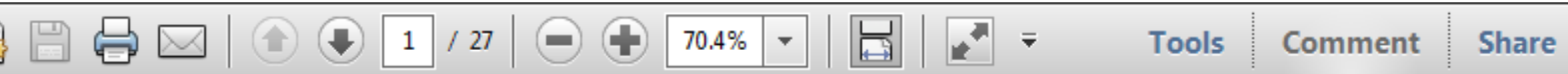

This will open up a panel down the right side of the document. The majority of tools you will use for annotating your proof will be in the Annotations section, pictured opposite. We've picked out some of these tools below:

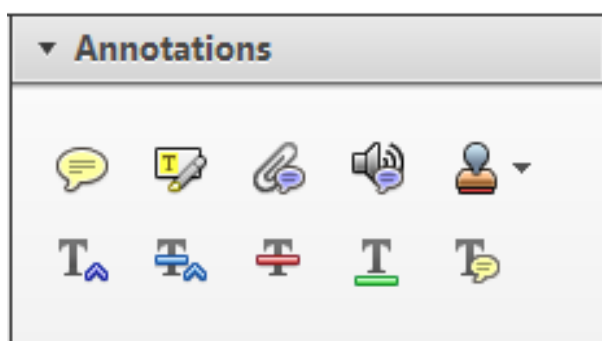

1. Replace (Ins) Tool - for replacing text.

Strikes a line through text and opens up a text box where replacement text can be entered.

How to use it

- Highlight a word or sentence

- Click on the Replace (Ins) icon in the Annotations section.

- Type the replacement text into the blue box that appears.

Idard tramework for the analysis of $\mathrm{m}$ icy-Nevertheless, it also led to exog،

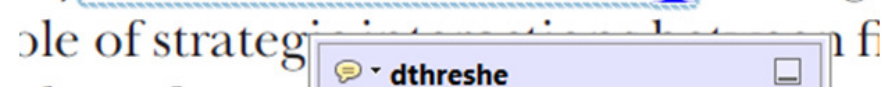
aber of comp 08/06/2011 15:58:17 is that the $\mathrm{s} 1 \overline{\text {, which led }}$ of nain compo: be level, are exc nc

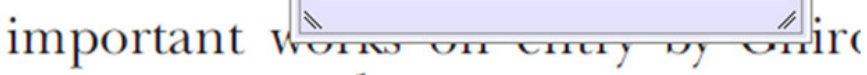
M henceforth) ${ }^{1}$ we snen the "hlark $\mathrm{h}$

3. Add note to text Tool - for highlighting a section to be changed to bold or italic.

Th Highlights text in yellow and opens up a text box where comments can be entered.

\section{How to use it}

- Highlight the relevant section of text.

- Click on the Add note to text icon in the Annotations section.

- Type instruction on what should be changed regarding the text into the yellow box that appears

namic responses of mark ups ent with the VAR evidence

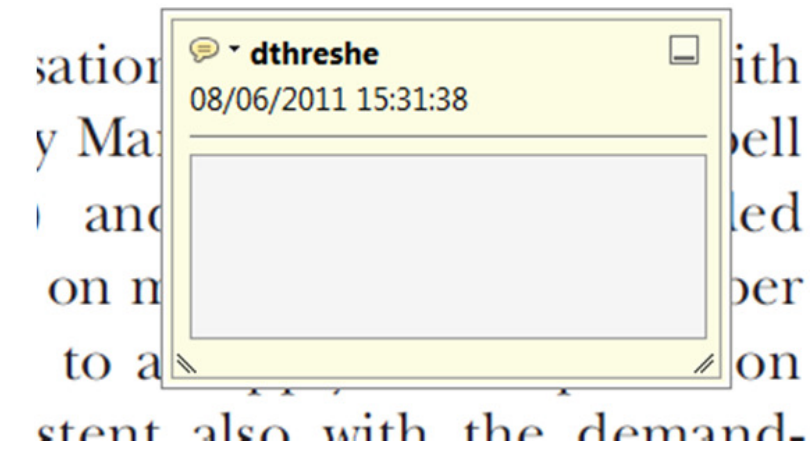

2. Strikethrough (Del) Tool - for deleting text.

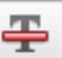

Strikes a red line through text that is to be deleted.

How to use it

- Highlight a word or sentence.

- Click on the Strikethrough (Del) icon in the Annotations section.

there is no room tor extra prohts al s ups are zero and the number of ret) values are not determined by Blanchard and Kiyotaki (1987), sfect competition in general equilil ts of aggregate demand and supply lassical framework assuming mono sen on evorenous nimher of firms

4. Add sticky note Tool - for making notes at specific points in the text.

Marks a point in the proof where a comment needs to be highlighted.

How to use it

- Click on the Add sticky note icon in the Annotations section.

- Click at the point in the proof where the comment should be inserted.

- Type the comment into the yellow box that appears.

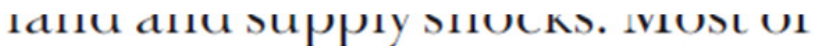

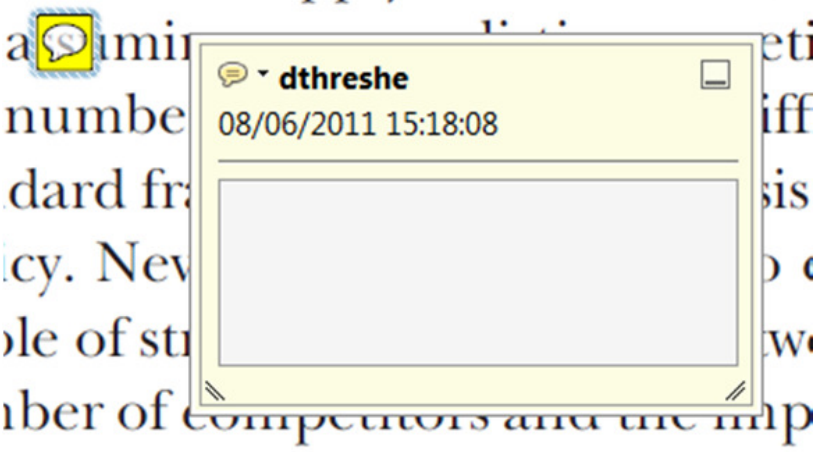

is that the structure of the sects. 
5. Attach File Tool - for inserting large amounts of text or replacement figures.

Inserts an icon linking to the attached file in the appropriate pace in the text.

How to use it

- Click on the Attach File icon in the Annotations section.

- Click on the proof to where you'd like the attached file to be linked.

- Select the file to be attached from your computer or network.

- Select the colour and type of icon that will appear in the proof. Click OK.

E N D

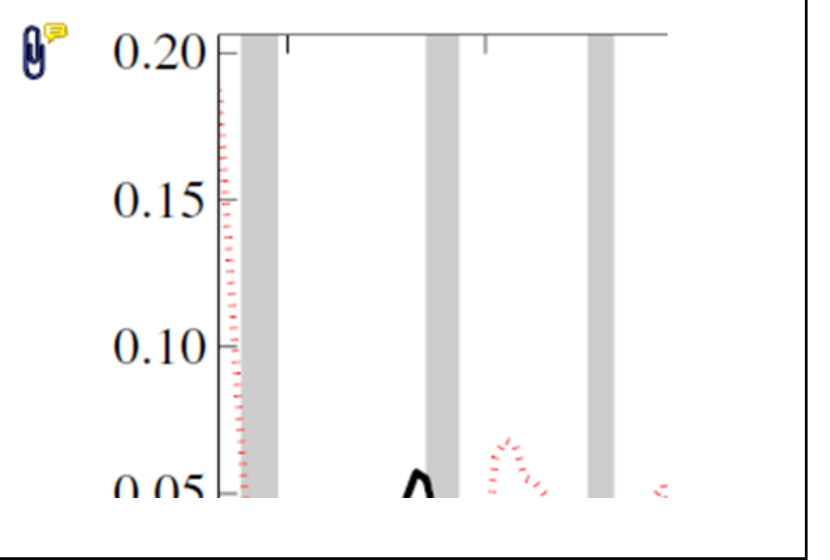

6. Add stamp Tool - for approving a proof if no corrections are required.

- Inserts a selected stamp onto an appropriate place in the proof

\section{How to use it}

- Click on the Add stamp icon in the Annotations section.

- Select the stamp you want to use. (The Approved stamp is usually available directly in the menu that appears).

- Click on the proof where you'd like the stamp to appear. (Where a proof is to be approved as it is, this would normally be on the first page).

of the Dusiness cycie, starting with the on perfect competition, constant ret

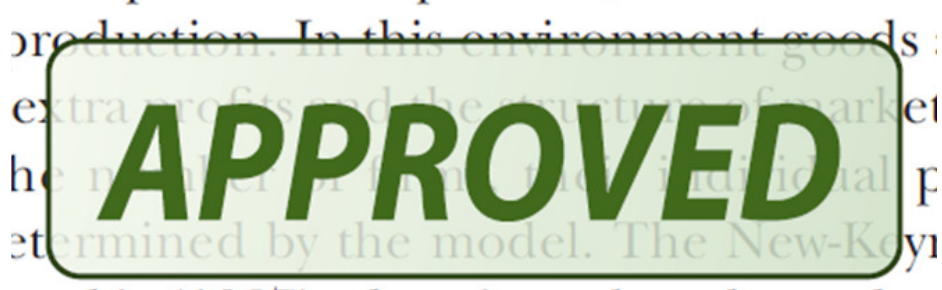
otaki (1987), has introduced produc general equilibrium models with nomin:

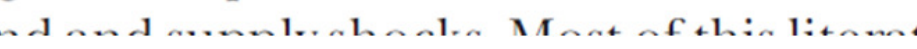

- Drawing Markups

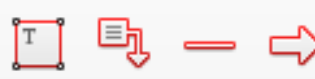

$0 \square \sqrt{ } \rightarrow 0$

\section{How to use it}

- Click on one of the shapes in the Drawing Markups section.

- Click on the proof at the relevant point and draw the selected shape with the cursor.

- To add a comment to the drawn shape, move the cursor over the shape until an arrowhead appears.

- Double click on the shape and type any text in the red box that appears.
7. Drawing Markups Tools - for drawing shapes, lines and freeform annotations on proofs and commenting on these marks.

Allows shapes, lines and freeform annotations to be drawn on proofs and for comment to be made on these marks.

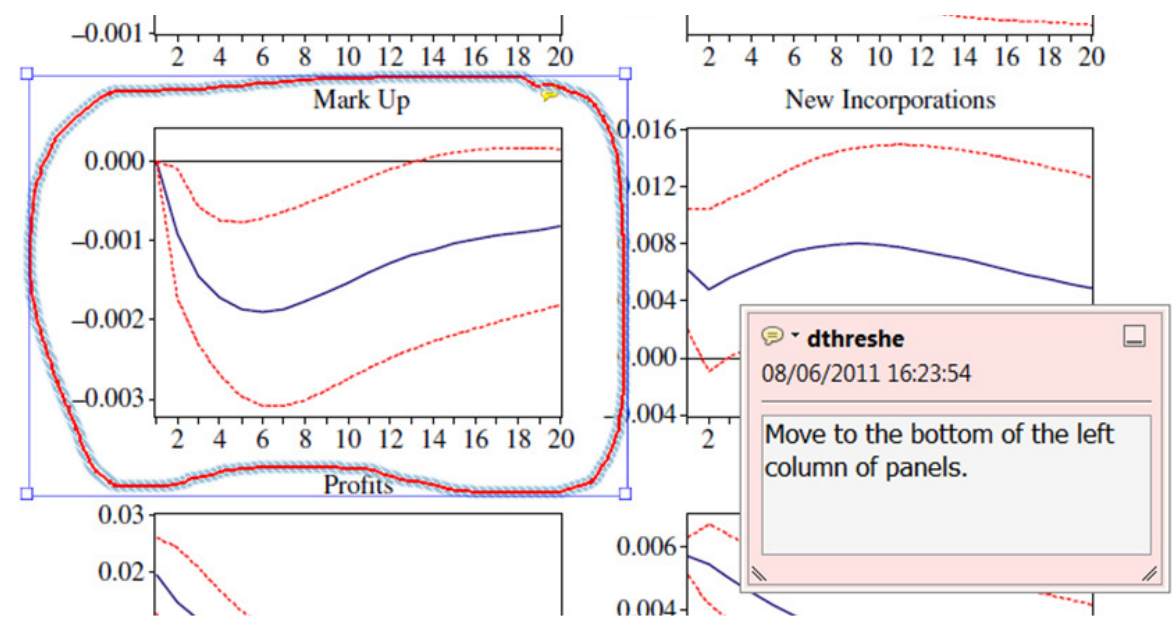

For further information on how to annotate proofs, click on the Help menu to reveal a list of further options:

\begin{tabular}{|l|l|l|l|l|l|l|}
\hline File ecoj_2384_CrxRev2_EV_19-Jul-10.pdf - Adobe Reader & Edit View Window \\
\hline
\end{tabular}

